$$
\begin{aligned}
& \text { Fessia مطالعه اثر ضدميكروبى عصارههاى متانولى، اتانولى و آبى كونه هايى از سرده } \\
& \text { بر روى برخى باكترىهاى بيمارىزا و قارج كانديدا آلبيكانس }
\end{aligned}
$$

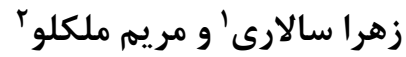

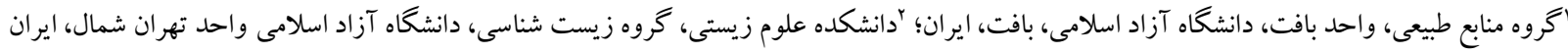

$$
\begin{aligned}
& \text { مسئول مكاتبات: زهرا سالارى، Salari@iaubaft.ac.ir }
\end{aligned}
$$

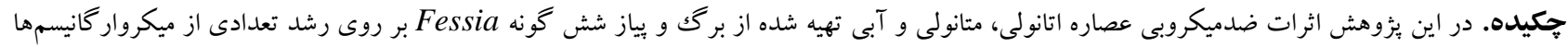

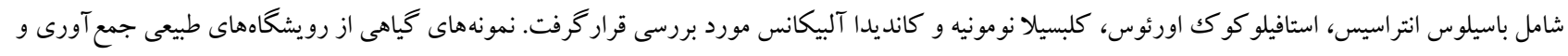

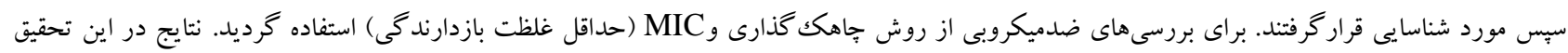

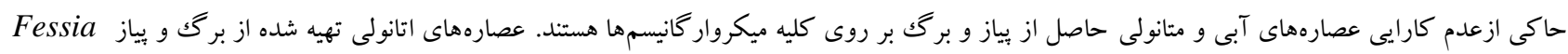
khorassanica وازههاى كليدى. استافيلو كو كث اورئوس، باسيلوس آنتراسيس، حداقل غلظت بازدارندگى، روش جاهك گذارى، كلبسيلا نومونيه

\title{
The study of antimicrobial effects of ethanolic, methanolic and aqueous extracts of six species of Fessia (Asparagaceae) on some pathogenic bacteria and Candida albicans
}

\author{
Zahra Salari $^{1} \&$ Maryam Malekloo $^{2}$ \\ ${ }^{1}$ Department of Natural Resources, Baft Branch, Islamic Azad University, Baft, Iran; ${ }^{2}$ Biology Department, North \\ Theran Branch, Islamic Azad University, Tehran, Iran \\ Correspondent author: Zahra Salari, Salari@iaubaft.ac.ir
}

\begin{abstract}
In this research, the antimicrobial effects of ethanolic, methanolic and aqueous extracts obtained from aerial parts, leaves and bulbs of six species of Fessia were investigated on the growth of some of micro-organisms, including Staphyloccocus aureus, Bacillus anthracis, Kelebsiella pneumonia and Candida albicans. Plant samples were collected from natural habitats and were then identified. The evaluation diameter of inhibitory zone, well and MIC (minimum inhibitory concentration) methods were used for the assessment. Aqueous and methanolic extracts obtained from the leaves and bulbs did not affect any of the studied micro-organisms. The results showed that ethanolic extract of the species Fessia khorassanica, had stronger inhibitory effect on the Candida albicans in comparison with the control group.
\end{abstract}

Keywords. Bacillus anthracis, Kelebsiella pneumonia, MIC, Staphyloccocus aureus, Well method 
ضد ميكروبى بين گگنههاى مورد مطالعه درتحقيقات داخلى و

مقلدما

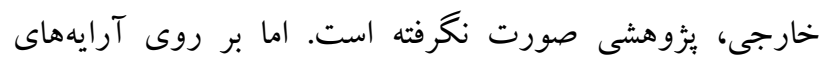

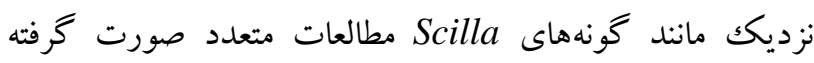

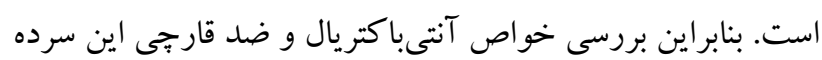
بيشنهاد مىشود. در اين يُزوهش از باكترىهاى گرم مثبت و گرم منفى و قارج كانديدا آلبيكانس در بررسى اثرات ضدميكروبى استفاده گرديد.

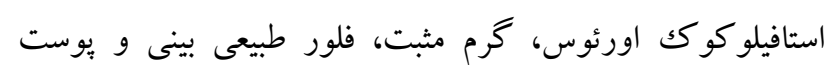

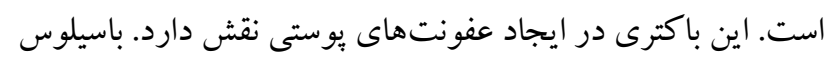

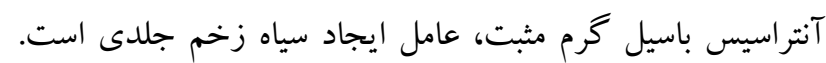

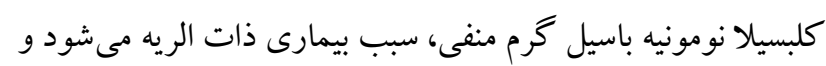

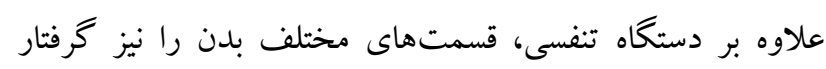

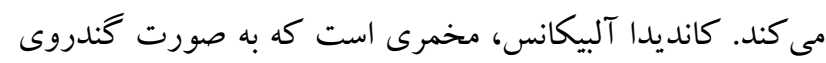

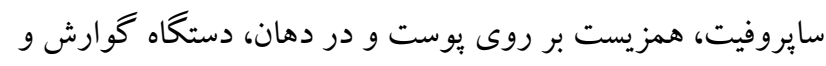

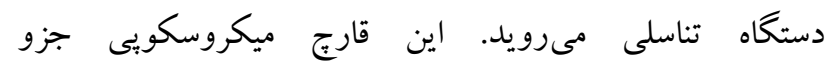

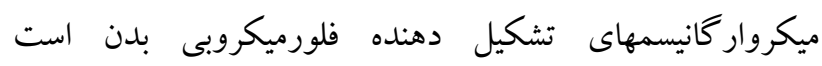

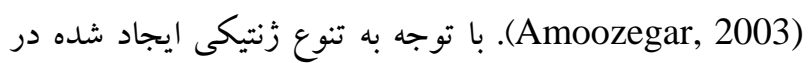

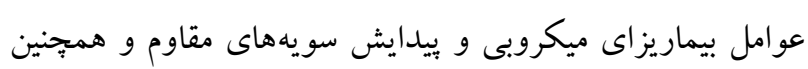
عوارض جانبى ناشى از مصرف داروهاى شيميايى، جايكزين كردن

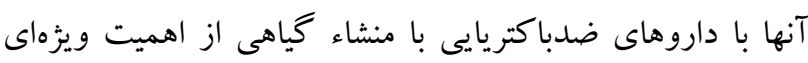

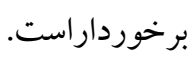

\section{مواد و روشها}

نمونههاى گياهى از رويشگاههاى طبيعى جمع آورى شده و باد إنا

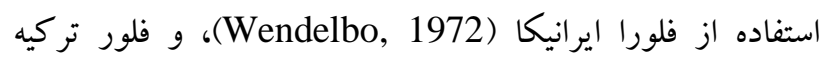

(Davis, 1984) جهت بررسى اثرات ضدميكروبى، اندامهاى رويشى شامل بياز و

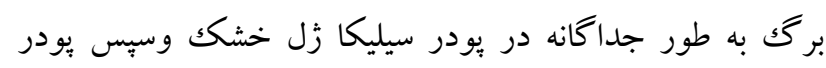

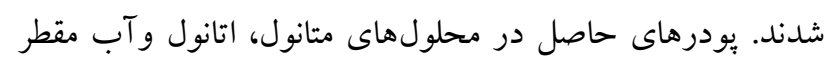

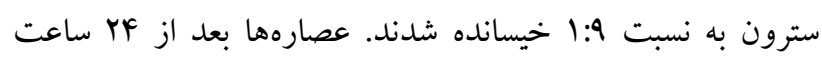
صاف وبه روش تنداليزاسيون سترون گرديدند.

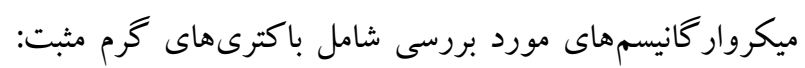

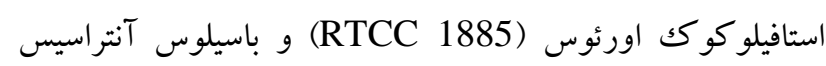
RTCC و باكترى گرم منفى: كلبسيلا نومونيه (RTCC 1036)

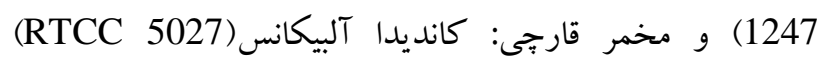
در سالهاى اخير مصرف بيش از اندازه آنتى بيوتيككها به مشكل

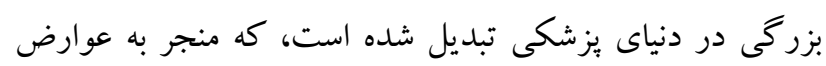

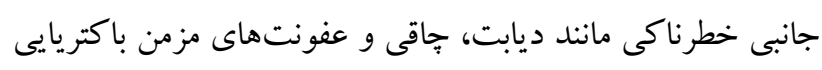

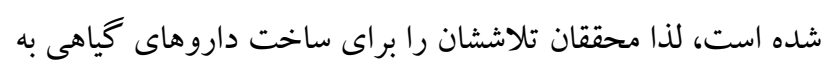

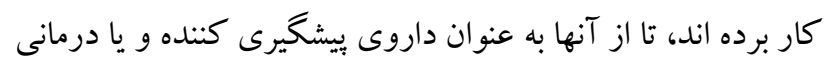

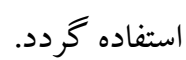
سرده Fessia Speta توسط اسيتا به عنوان سرده جداكانه با ويز گىهاى، بياز با بوشش مشكى و يا خاكسترى، ساقها دارداى

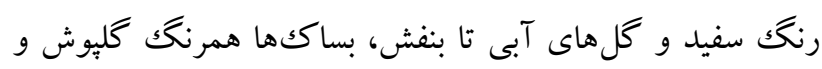

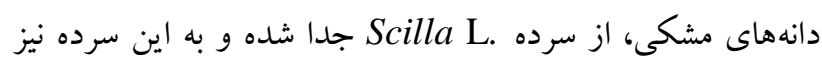
بسيار نزديك است. كونهاي Fessia assadii Malekloo, Hamdi \& Joharchi Fessia gorganica ‘Fessia bisotunensis (Speta) Speta „Fessia greilhuberi (Speta) Speta ،(Speta) Speta g Fessia hohenackeri (Fisch. \& C.A.Mey.) Speta Fessia khorassanica (Meikle) Speta هستند (Malekloo et al. 2014; Speta 1998 a, b). Scilla scilloides (Lindl) آزمايشات انجام شده بر روى

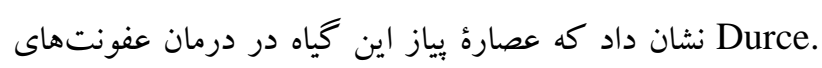

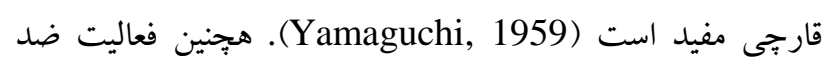

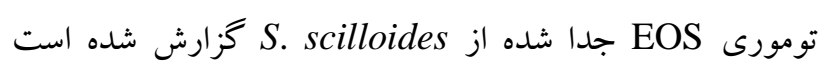
S. persica Hausskn. از كياه (Kakeagawa et al., 1988)

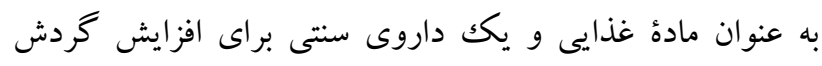

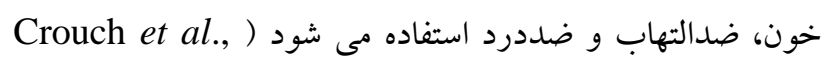

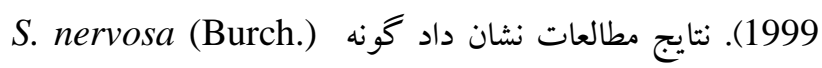
داراى تركيبات هوموايزوفلاونوس هستند كه امروزه د.P.Jessop

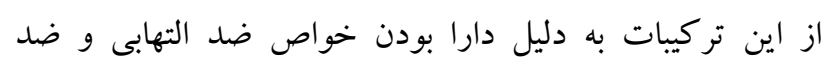
ميكروبى بسيار استفاده مى شود (Bangani, 1999).

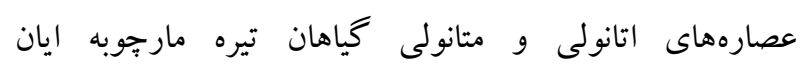
Aspargaceae داراى خاصيت ضد ميكروبى و ضد قارجى است.

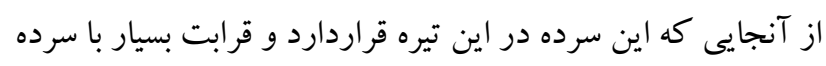

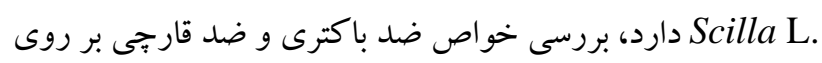

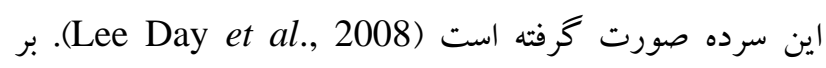
اساس بررسى هاى انجام شده درخصوص بررسى مقايسه اى اثرات 
نواحى مديترانهاى، جنوب ارويا، مركز وغرب آسيا، آفريقا براكندگى دارد (Mario et al., 2011). محل رويش آرايههاى سرده Scilla از مناطق نيمه بيابانى خشك دارد

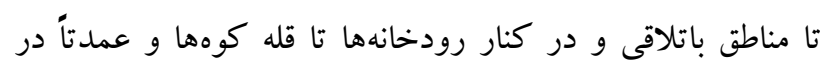
شكاف تختهنگكها و در زير سايه گياهان ديخر است. اين گياهان

$$
\text { سايه دوست هستند. }
$$

tRNA بر اساس مطالعات مولكولى بر روى زنوم كلرويلاست هاء L- F Othocallis ،Prospero Salisb. “Fessia Speta Zagrosia Speta. و و با بوتستراب 99 دور صد تائيد

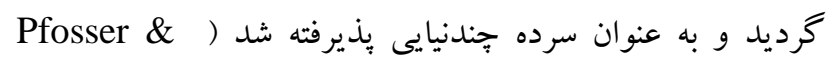

.(Speta, 1999

نتايج حاصل ازبررسى عصاره اتانولى، متانولى و آبى برك و بياز

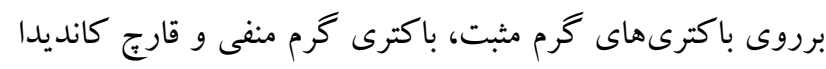

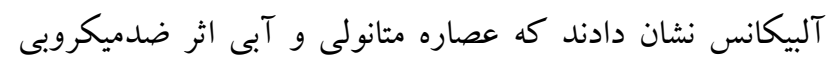

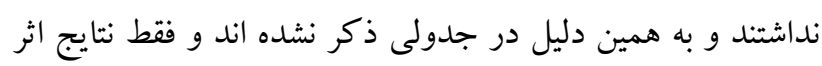

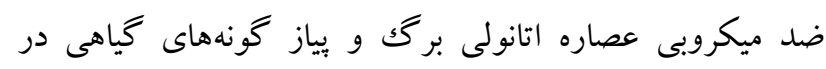
جدول هاى اوب قرار گرفته است.

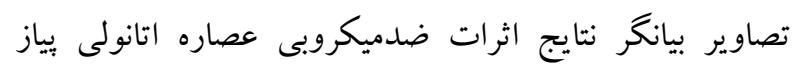

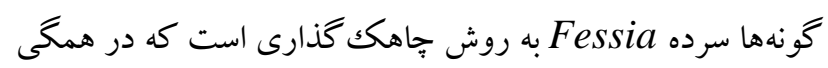

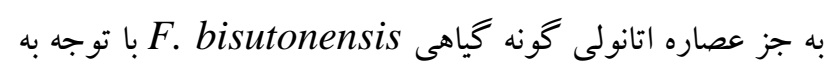
شاهد، اثر ضدميكروبى خشمخيرى داشت (شكل () ).

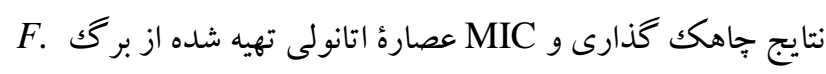
khorassanica

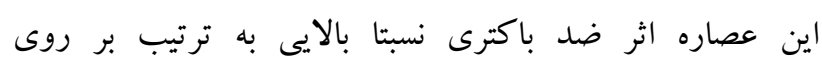
استافيلو كو كوس اورئوس، باسيلوس آنتراسيس و كلبسيل انومونيه

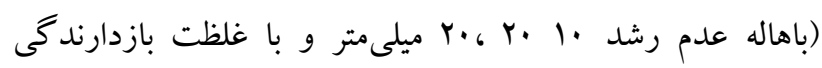

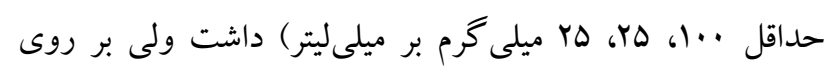
قارج كانديدا آلبيكانس اثر ضد ميكروبى نداشت.

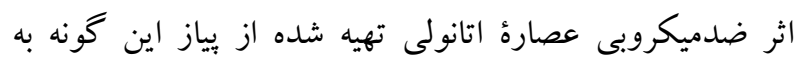
ترتيب بر روى استافيلوكوكوس اورئوس، باسيلوس آنتراسيس،

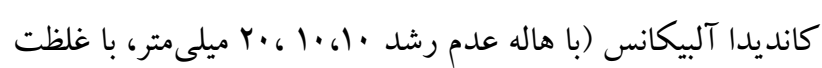

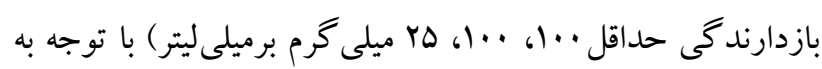

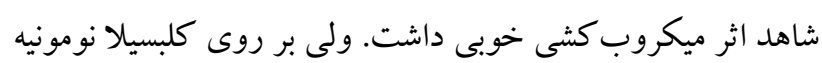
اثرمهار كنندكى ميكروبى نداشت.
بودند، كه از موسسه تحقيقاتى رازى تهيه شدند. محيطهاى كشت برين هارت اينفيوزن براث (مركك)، نوترينت آكار (مركى)، سابرو

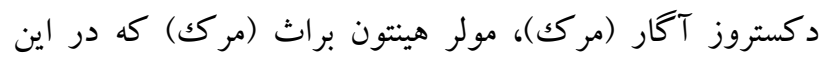
تحقيق استفاده شد. جهت غنىسازى سويههاى باكتريايى و قارجى از محيط كشت ست

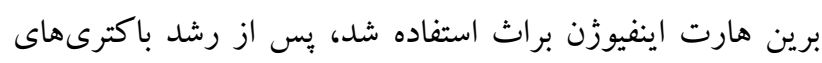

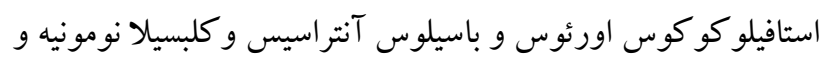

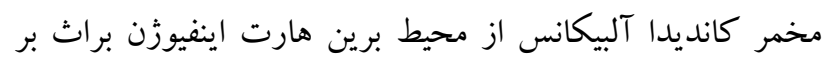

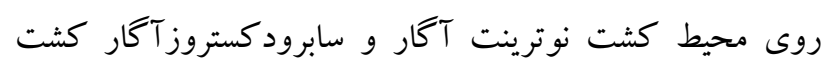

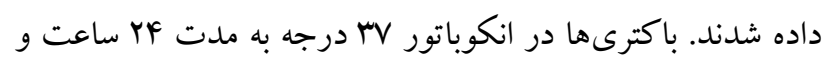

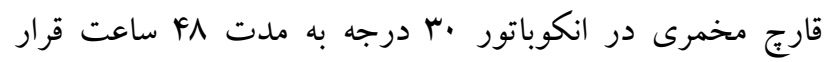

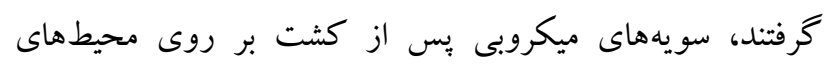

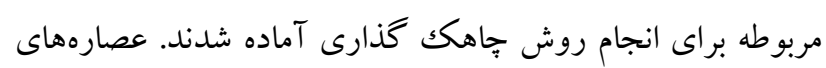

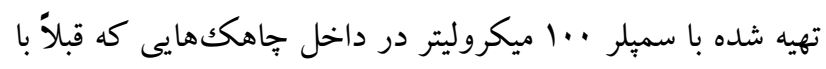

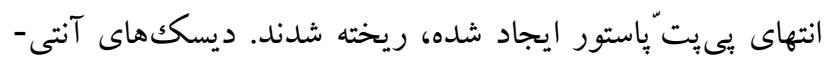

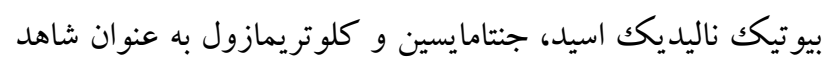
بر روى محيط كشت منتقل گرديدند، در تمام نمونهها از اتانول،

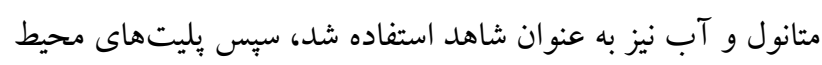

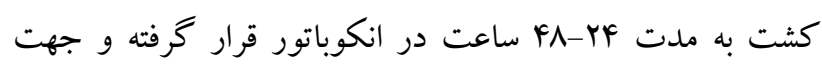
بررسى خاصيت ضدميكروبى از روش سنجش قطر هاله عدم رشد

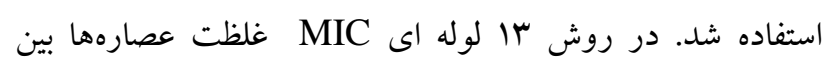

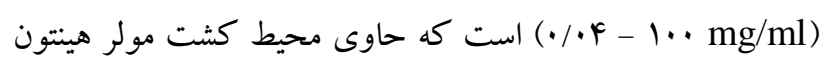

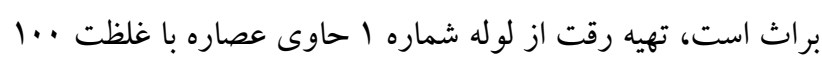

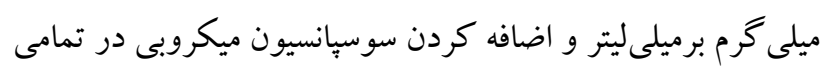

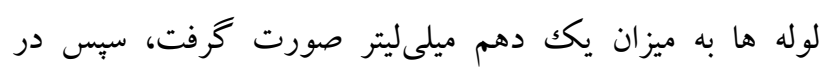

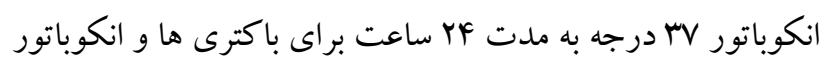

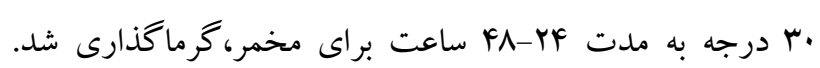

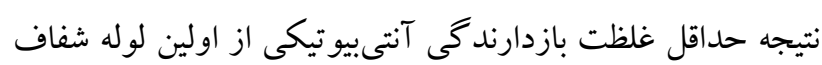
قبل ازشروع لولههاى حاوى كدورت ميكروبى در روش تعيين شد (Ashrafi, 2011). نتايج سرده Scilla از گياهان علفى يياز دار است كه در زيرتيره

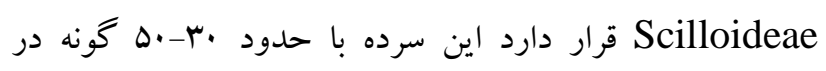


جدول ا- اثرات ضد باكتريايى و ضد قارجى عصاره بركى اتانولى گياه Fessia به روش خاهك كذارى (قطر هاله مهار رشد به ميلىمتر) و MIC

Table 1. Anti-bacterial and anti-fungal effects of ethanolic leaf extracts of Fessia species by well \& MIC methods.

\begin{tabular}{|c|c|c|c|c|c|c|c|c|c|c|c|}
\hline $\begin{array}{c}\frac{6}{2} \\
3 \\
3 \\
3 \\
3 \\
3\end{array}$ & 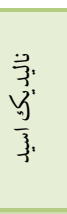 & $\begin{array}{l}\frac{3}{3} \\
3 \\
3\end{array}$ & $\begin{array}{l}\frac{3}{3} \\
\frac{3}{5} \\
3 \\
3\end{array}$ & 离 & 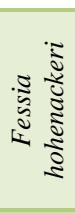 & 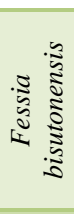 & 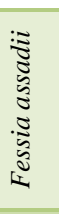 & 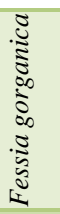 & 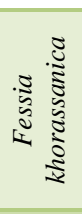 & 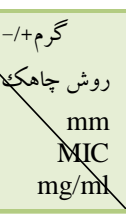 & ميكروار كانيسمهاى \\
\hline- & 1. & $r$. & - & - & - & - & $\begin{array}{l}\text { iv } \\
\Delta .\end{array}$ & - & $\begin{array}{l}1 . \\
1 . .\end{array}$ & + & استافيلو كو كث اورئوس \\
\hline - & ro & ro & - & - & $\begin{array}{l}1 . \\
1 . .\end{array}$ & $\begin{array}{l}\text { r. } \\
\text { ro }\end{array}$ & $\begin{array}{l}1 . \\
1 . .\end{array}$ & $\begin{array}{l}1 . \\
1 \ldots\end{array}$ & $\begin{array}{l}r . \\
r \Delta\end{array}$ & + & باسيلوس انتراسيس \\
\hline- & $r$. & r. & - & - & - & - & - & - & - & - & كلبسيلا ينومونيه \\
\hline 11 & - & - & - & $\begin{array}{l}10 \\
\Delta .\end{array}$ & - & $\begin{array}{l}1 . \\
1 . .\end{array}$ & - & - & $\begin{array}{l}\text { r. } \\
\text { ro }\end{array}$ & قارج & كانديدا آليكانس \\
\hline
\end{tabular}

جدول r- اثرات ضد باكتريايى و ضد قارجى عصارة بياز اتانولى گياه Fessia به روش حاهك كذارى (قطر هاله مهار رشد به ميليمتر) و MIC

Table 2. Anti-bacterial and anti-fungal effects of ethanolic bulb extracts of Fessia species by well \& MIC methods.

\begin{tabular}{|c|c|c|c|c|c|c|c|c|c|c|c|}
\hline $\begin{array}{c}y \\
3 \\
3 \\
3 \\
3 \\
3 \\
3\end{array}$ & 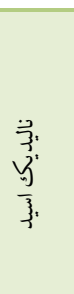 & $\frac{3}{3}$ & $\begin{array}{l}\frac{43}{3} \\
\frac{1}{\frac{1}{2}} \\
3 \\
3\end{array}$ & 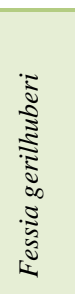 & 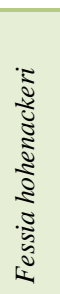 & 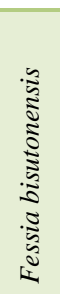 & 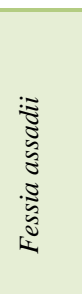 & 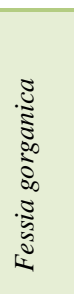 & 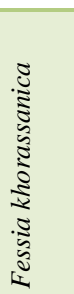 & 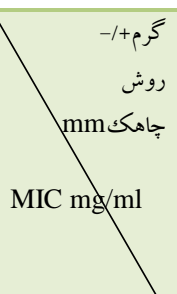 & ميكروار كانسمهاى مورد \\
\hline- & 1. & $r$. & - & - & - & - & $\begin{array}{l}10 \\
1 . .\end{array}$ & - & $\begin{array}{l}1 . \\
1 . .\end{array}$ & + & استافيلوكو كث اورئوس \\
\hline- & ro & ro & - & - & - & - & $\begin{array}{l}1 . \\
1 . .\end{array}$ & $\begin{array}{l}1 . \\
1 . .\end{array}$ & $\begin{array}{l}1 . \\
1 . .\end{array}$ & + & باسيلوس انتراسيس \\
\hline- & $r$. & $r$. & - & - & - & - & - & - & $\begin{array}{l}\text { r. } \\
\text { ro }\end{array}$ & - & كلبسيلا ينومونيه \\
\hline is & - & - & - & $\begin{array}{l}\text { is } \\
\text { ro }\end{array}$ & $\begin{array}{r}r . \\
r \Delta\end{array}$ & - & - & - & - & قارج & كانديدا آليكانس \\
\hline
\end{tabular}

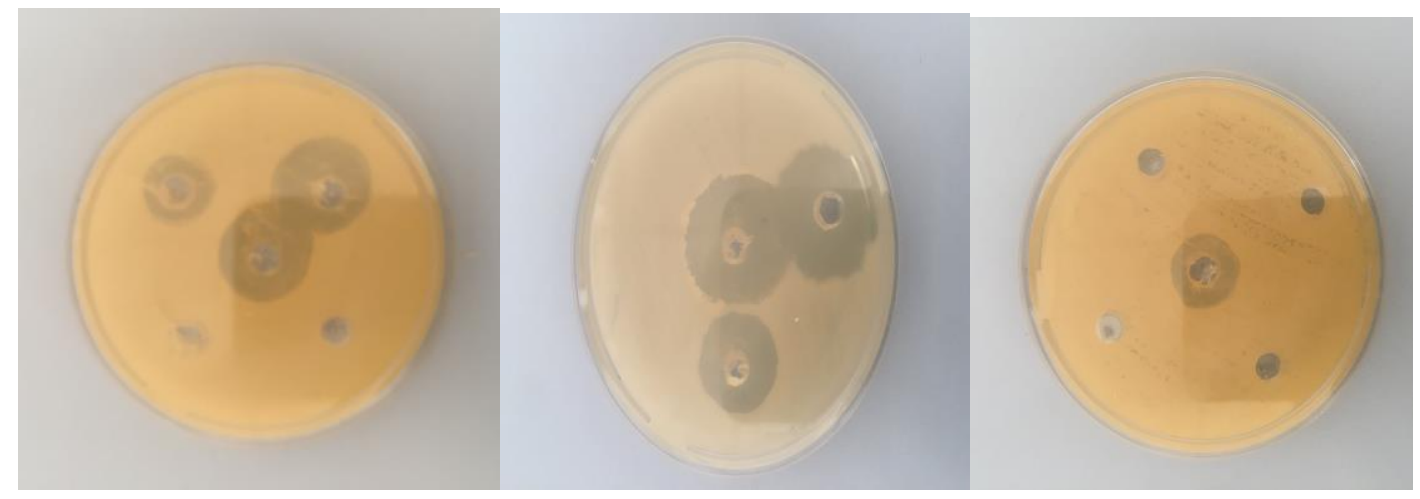

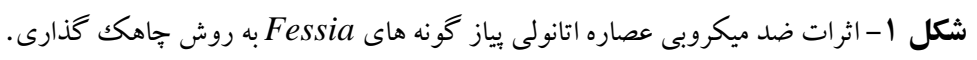

Fig.1. Anti-microbial effect of ethanolic bulb extract of Fessia species by well method. 
(هاميلى متر حداقل غلظت بازدارندگى •ه ميلى گرم برليتر ) با توجه به شاهد اثر ضد قارجى نسبتا خوبى داشت.

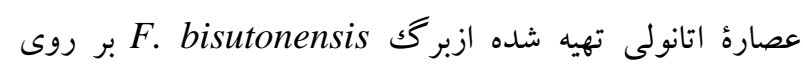
باكترى گرم منفى و قارج كانديدا آليكانس با توجه به شاهد اثر مهارى ضد ميكروبى قابل قبولى نداشتند.. ولى عصاره اتانولى يياز

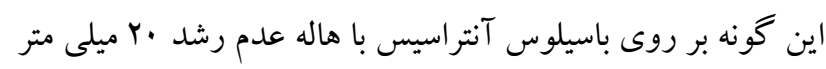

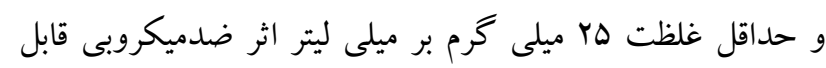
تو جهى داشت.

\section{بحث}

با توجه به نزديك بودن سرده Scilla و Fessia به يكديخر،

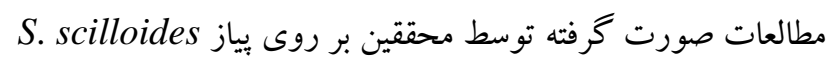

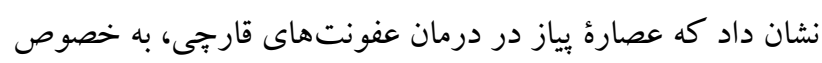

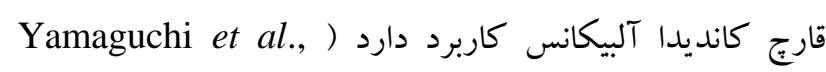

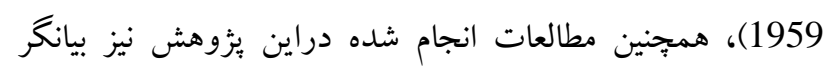

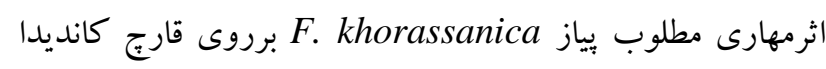

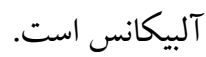

بررسىهاى انجام شده نشان داده است كه عصاره هگز ان نرمال

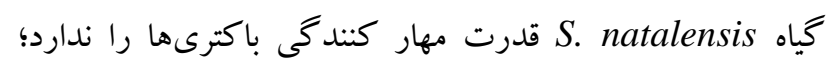
عصاره آبى قدرت مهار كنندگى ضعيفى دارند. در حاليكه عصارة

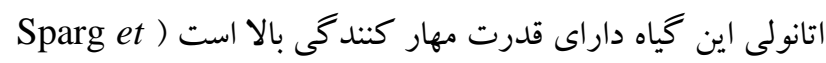

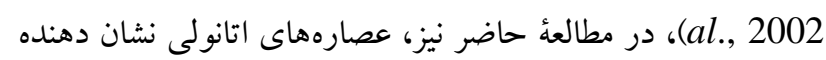

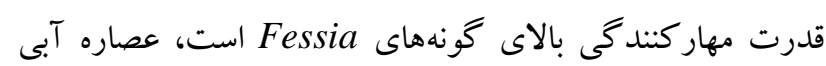
قدرت مهار كنندگى ندارد. نتيجه مطالعات نشان داده كه فلاونوئيدها اثرات ضد مئد ميكروبى دارند

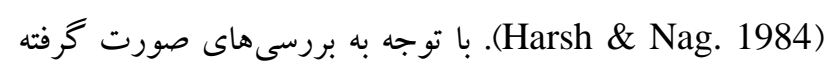

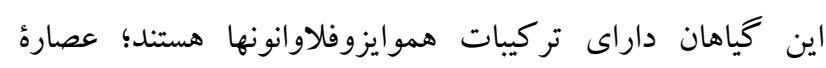
اتانولى به دليل مقاديربالايى از فلاونوئيدها داراى خائ خاصيت

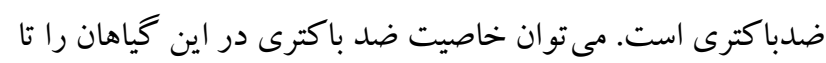

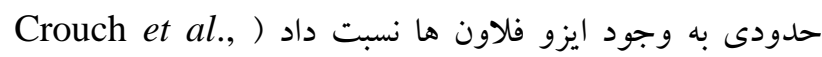

متخصصين معتقدند كه خاصيت دارويى گليكوزيدها، مربوط به قسمت غيرقندى مولكول است و هيدروليز كليكوزيدها به وسيله آنزيمها، اسيدهاى رقيق و قلياها سبب آزاد سازى تركيبات قندى وندي

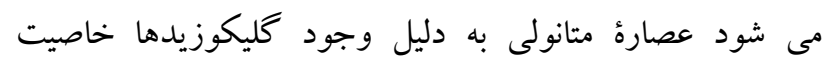

Fت تنايج كار ضدميكروبى عصاره اتانولى تهيه شده از برك

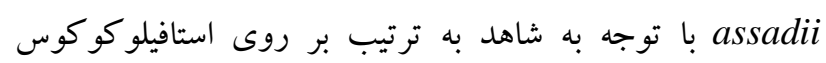

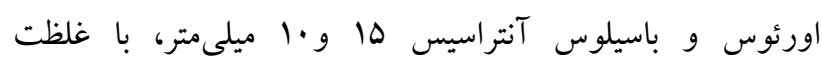

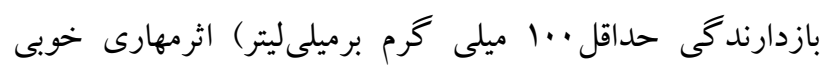

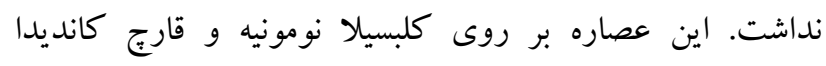
آلبيكانس تاثير ضد ميكروبى نداشت. عصارة اتانولى تهيه شده از

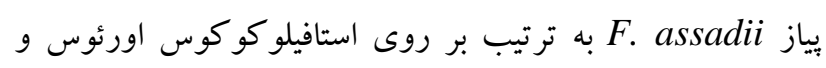

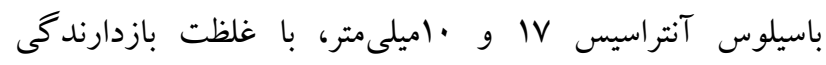

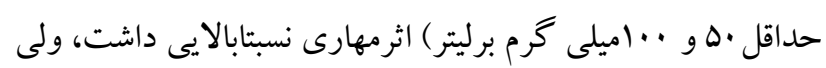

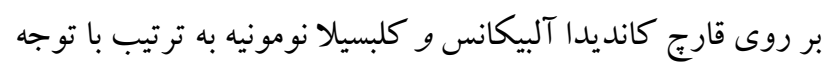
به شاهد كلوتريمازول و جنتامايسين و ناليديكسيك اسيد اثر مهارى نداشت. عصارة اتانولى تهيه شده از برگك Forganica

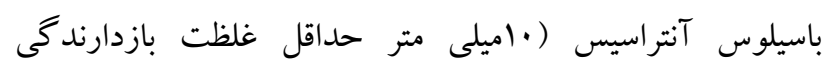

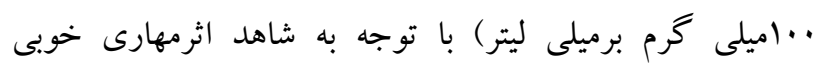
نداشت. بر روى استافيلو كو كوس اورئوس، كلبسيلانومونيه و قارج

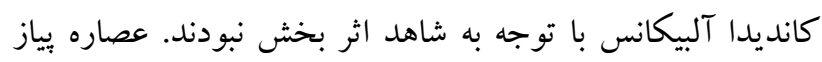

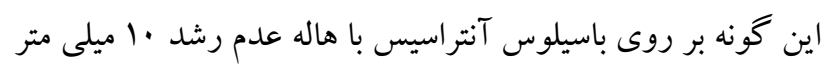

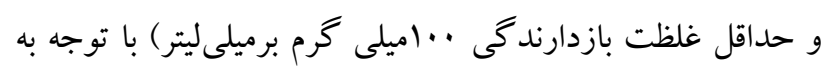
شاهد موثر واقع نشد. عصارة اتانولى تهيه شده از بركى Fohenackeri

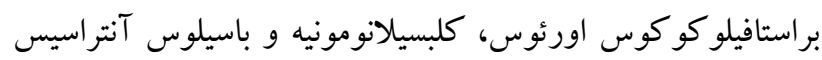

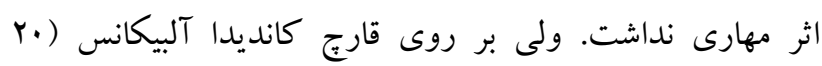

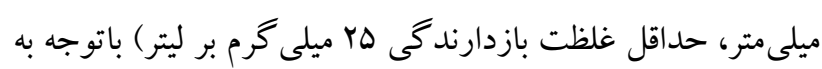

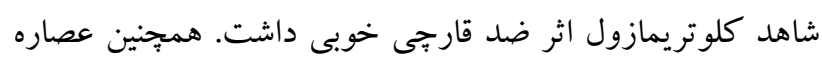

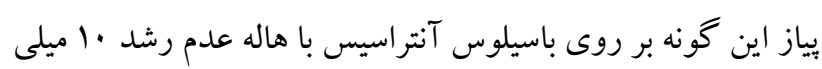

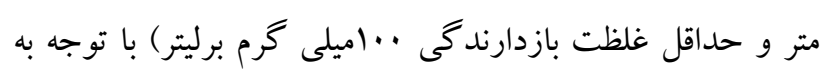
شاهد موثر واقع نشد. عصارة اتانولى تهيه شده از بركى Ferilhuberii

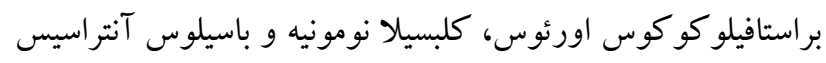

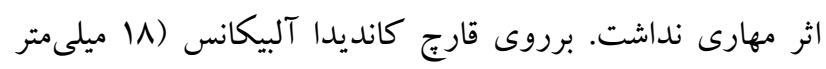

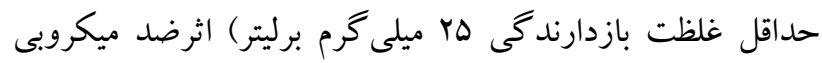

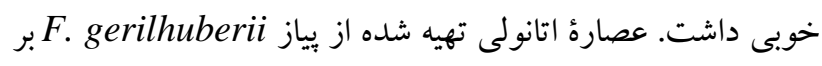

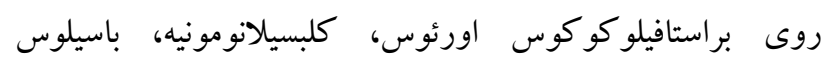

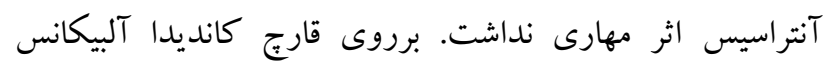


يا ساير بيمارىهاى قارجى مى گردد، كه درمان آن معمولاً با بماد

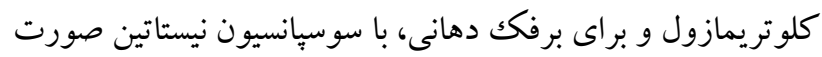

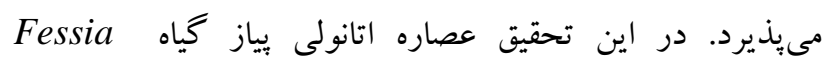
khorassanica

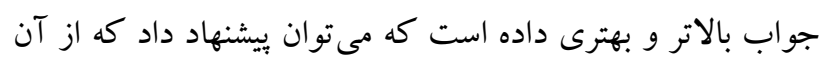

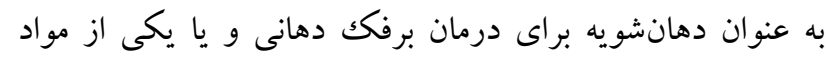
موثره در يماد جلدى در درمان عفونتهاى جلدى ناشى از اين قارج استفاده گردد.

\section{سياسگزْ ارى}

بدينوسيله ازهمكاران حوزه يُزوهش دانشكاه آزاد اسلامى واحد

$$
\text { بافت قدردانى مى گردد. }
$$

\section{REFERENCES}

Ashrafi, F. 2011. Practical microbiology together with biochemical function. - Ahsan Press, Tehran. pp: 5168, 190-199.

Amoozegar, M.A. 2003. Microbiology. - Pooran Pajoohesh Press, Tehran.

Bangani, V., Crouch, N.R. and Mulholland, D.A. 1999. Homoisoflavanones and stilbenoids from Scilla nervosa. - Phytochemistry 51: 947-951.

Crouch, N.R., Bangani, V. and Mulholland, D.A. 1999. Homoisoflavanonesfrom three South African: Scilla species. - Photochemistry 51: 943-946.

Hafez Ghoran, S., Mighani, H. and Ebrahimi, P. 2014. In-vitro antibacterial activity of chloroform, ethylacetate and hydroalcohlic extracts of Scilla persica Hausskn. - J. Gorgan Univ. Medic. Sci. 16: 106-113.

Harsh, M.L. and Nag, T.N. 1984. Antimicrobial principal From in vitro tissue culture of Peganum harmala. - J. Nat. Prod. 47: 365-367.

Karen, d., Audrey, K. and Johannes, B. 2011. Antiinflammatory and antimicrobial profiles of Scilla nervosa (Burch) Jessop (Htyacinthaceae). - S. Afr. J. Sci. 107: 5-6.

Kakeagawa, H., Matsumoto, H. and Satoh, S. 1988. Planatamed. 54: 385-389.

Kayıran, S.D. and Özkan, E.E. 2017. The ethnobotanical uses of Hyacinthaceae species growing in Turkey and a review of pharmacological activities. - Indian J. Tradit. Know. 16: 243-250.

Lee, D., Choobk, Y., Cheon, M., Lee, H., Lee, A. and Kim, H. 2009. Anti-inflammatory effects of Asparagus cochinchinesis extract in actute and chronic cutaneous inflammation. - J. Ethonopharmocol. 121: 28-3.

Malekloo, M., Nejadsattari, T., Hamdi, S.M. and Mehregan, I. 2014. Fessia assadii (Asparagaceae), a new species from Iran. - JBES 5: 78-85.

Mario, M., Manuel, B., Crespo, A., Juan, I. and Fay, M.F. 2011. Molecular phylogenetics of subfamily
ضدميكروبى ندارد (Martínez-Azorín et al., 2011). نتايج اين

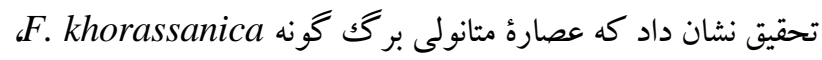

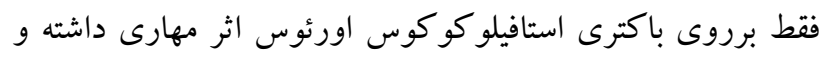

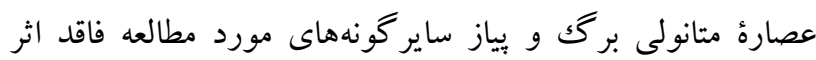

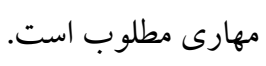

بررسى اثرضد ميكروبى عصارههاى كلروفرمى، اتيل استاتى و هيدروالكلى يياز سنبل كوهى نشان دادند كه، عصارة اتانولى يياز داراى قدرت مهار كندگى بيشترى است ( Hafez Ghoran et .(al., 2014

S. bifolia L. بررسىهاى صورت گرفته نشان داد كه يِياز گونه

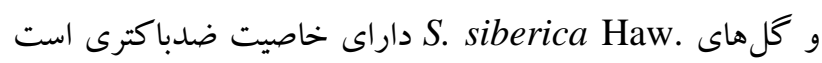
(Kayıran \& Özkan, 2017)

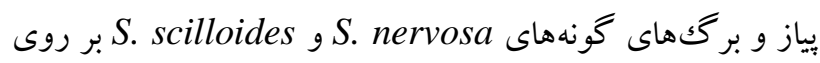
استافيلو كو كوس اورئوس و كانديدا آلبيكانس خاصيت ضدباكياكترى و ضدقارجى دارند (Kayiran \& Ozkan, 2017). مطالعات ديخرى بيان كرده است كه عصاره اتانولى و متانولى (مانى

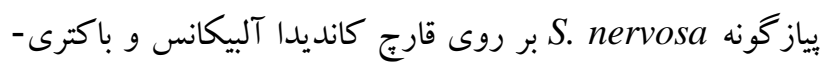
هاى كلبسيلا نومونيه و استافيلو كو كوس اورئوس اثر داشته و هاله

عدم رشد تشكيل شده است (Karen du Toit et al., 2011).

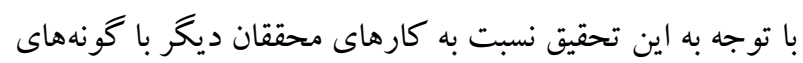

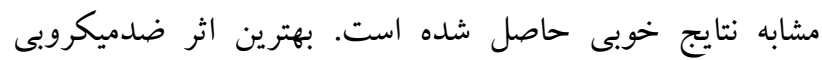

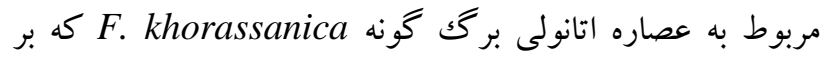

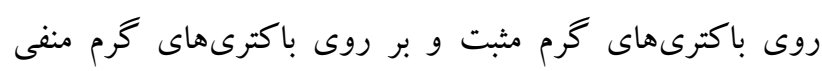

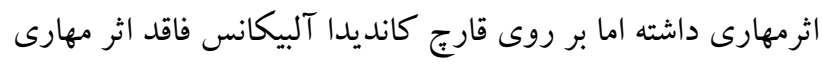

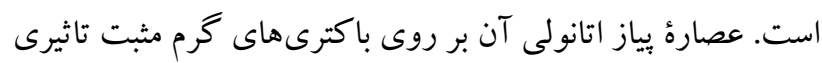
خوب و بر روى قارج اثر مهارى مطلوب داشت.

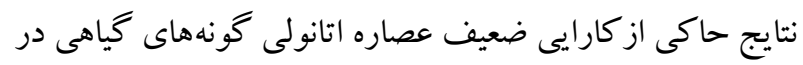
باكترى گرم منفى بوده است در حالى كه عصارههاى اتانولى اثر

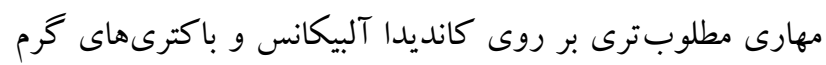

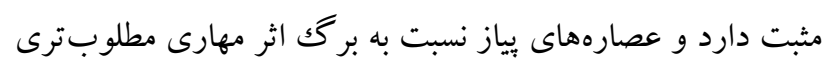
بر روى سوش هاى مورد مطالعه داشتند.

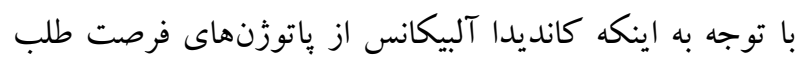

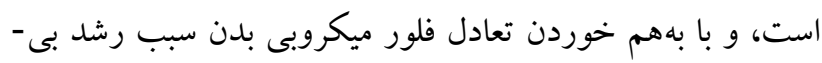

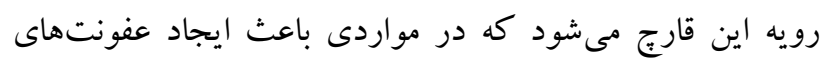
شديد ادرارى، مخاطى و جلدى، كانديديازيس وازن، برفك دهان 
fornithogaloideae (Hyacinthaceae) based on nuclear and plastid DNA regions, including a new taxonomic arrangement. - Ann. Bot. 107: 1-37.

Martínez-Azorín, M., Crespo, A., Manuel, B., Juan, I. and Fay, M.F. 2011. - Ann. Bot. 107: 1-3.

Mordak, E. V. 1984. Scilla L. - In: Davis, PH. (ed.), Flora of Turkey and the East Aegean Islands, 8: 214223. - Edinburgh University Press, Edinburgh.

Pfosser, M. and Speta, F. 1999. Phylogenetics of Hyacinthaceae based on Plastid DNA Sequences. Ann. Missouri Bot . Gard. 86: 852-875.

Speta, F. 1998a. Hyacinthaceae. - In: Kubitzki, K. (ed.), The families and genera of vascular plants. Springer, Berlin. pp: 261-285.
Speta, F. 1998b. Systematic analysis of the genus L. s. 1. (Hyacinthaceae). - Phyton 38: 1- 141.

Sparg, S.G., Van Staden, J.S. and Jager, A.K. 2002. pharmacological and phytochemical screening of two Hyacinthaceae species: Scilla natalensis and Ledeboria ovatifolia. - J. Ethnopharmacol. 80: 95101.

Wendelbo, P. 1972. Scilla L. - In: Rechinger, K.H. (ed.), Flora Iranica. vol. 155: 107-119. - Akad. Druck- und Verlagsanstalt, Graz.

Yamaguchi, T. 1959. The journey of the Lycoris radiate herb to Japanas a relief plant in a rice lean year. - Nat. Sci. Mus. Tokyo. 26: 147-153.

How to cite this article:

Salalri, Z. and Malekloo, M. 2019. The study of antimicrobial effects of ethanolic, methanolic and aqueous extracts of six species of Fessia (Asparagaceae) on some pathogenic bacteria spp. and Candida albicans. - Nova Biol. Reperta 6: 254-260.

سالارى، ز. و ملكلو، م. ^وسا. مطالعه اثر ضدميكروبى عصارههاى متانولى، اتانولى و آبى گونهايى از سرده Fessia بر روى برخى باكترىهاى بيمارىزاو قارج كانديدا

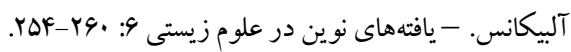


